\section{Commentary: The Bentall procedure: What's in a name?}

\author{
Alan M. Speir, MD
}

In this month's issue of the Journal of Thoracic and Cardiovascular Surgery, Mazine and colleagues ${ }^{1}$ present an impressive review of their 24-year analysis from their noted cardiac center summarizing the results in 473 patients who underwent a Bentall procedure after a previous cardiac surgical procedure. Mazine and colleagues ${ }^{1}$ conclude that "reoperative aortic root replacement with a Bentall procedure is associated with a significant operative risk, even in experienced hands. The need for complex coronary reimplantation techniques is an important factor associated with predictor of adverse perioperative events." Not only are the clinical findings of their analysis are important in this challenging population of patients, also relevant is the opportunity to appreciate fully the applications of the myriad techniques in their series of Bentall procedures that have evolved in the surgical treatments of diseases of the anatomically complex structure known as the aortic root.

When Hugh Bentall and Anthony De Bono ${ }^{2}$ first described their operative procedure to treat proximal aortic pathology in 1968, the utilization of cardiopulmonary bypass to interrupt aortic blood flow had been available for more than a decade. Cooley and De Bakey ${ }^{3}$ initially introduced cardiopulmonary bypass to replace an aneurysm of the ascending aneurysm in 1956. What was novel about the procedure of Bentall and De Bono, however, was the introduction of a valve-synthetic graft composite and the concept of a side-to-side anastomosis of the ostia of the coronary arteries to the aortic composite graft.

With time, and with more experience with pathologies of the aortic root, it became apparent that there was not infrequently a population of patients who demonstrated significant lack of mobility of the coronary ostia that precluded or compromised the side-to-side coronary artery anastomosis

From the Inova Heart and Vascular Institute, Falls Church, Va.

Disclosures: Author has nothing to disclose with regard to commercial support.

Received for publication Dec 31, 2019; accepted for publication Jan 2, 2020; available ahead of print Jan 25, 2020.

Address for reprints: Alan M. Speir, MD, Inova Heart and Vascular Institute, 3300 Gallows Rd, Falls Church, VA 22042 (E-mail: alan.speir@inova.org).

J Thorac Cardiovasc Surg 2021;162:1072-3

$0022-5223 / \$ 36.00$

Copyright (c) 2020 by The American Association for Thoracic Surgery

https://doi.org/10.1016/j.jtcvs.2020.01.013

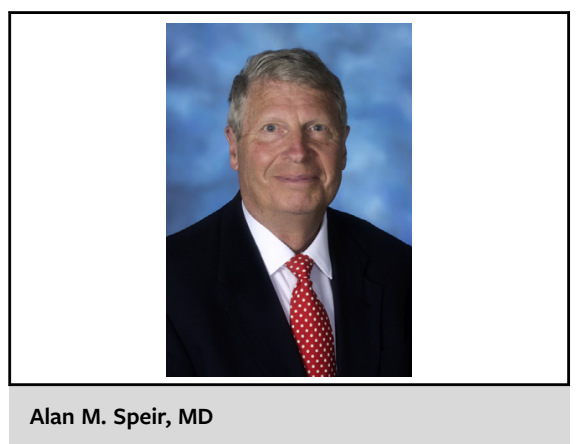

CENTRAL MESSAGE

The Bentall procedure hardly resembles its original description.

as Bentall described. Blanco and colleagues ${ }^{4}$ introduced initially a segment of Dacron polyester fabric graft and subsequently a saphenous vein graft as an interposition graft from the ostia of the coronary arteries to the side of the composite graft to facilitate implantation without tension and to improve visualization of the anastomoses. In 1978, Cabrol and associates ${ }^{5}$ modified the individual grafts with a single 8-mm Dacron polyester fabric graft anastomosed on each end to the ostia of the right and left coronary arteries, with a side-to-side connection to the composite graft. In 1991, Kouchoukos and coworkers ${ }^{6}$ contributed what was, in retrospect, the very important modification of preclotting the Dacron polyester fabric graft with albumin to improve hemostasis and excising the coronary ostia as "coronary buttons" to facilitate the aortic graft-coronary artery anastomosis.

Each of these techniques was demonstrated in a modified form in the referenced article of Mazine and colleagues, ${ }^{1}$ and despite the variability of coronary implantation techniques used, the clinical results speak for themselves. The surgeon's experience with such implantation techniques, either directly or with interposition grafts, is of critical importance to the outcomes of such complex procedures. The "Bentall procedure" has come a long way from its original description, with numerous important modifications and iterations. The name has endured. But really, what's in a name?

\section{References}

1. Mazine A, David TE, Lafreniere-Roula M, Feindel CM, Ouzounian M. Early outcomes of the Bentall procedure after previous cardiac surgery. J Thorac Cardiovasc Surg. 2021;162:1063-71. 
2. Bentall H, De Bono A. A technique for complete replacement of the ascending aorta. Thorax. 1968;23:338-9.

3. Cooley DA, De Bakey ME. Resection of entire ascending aorta in fusiform aneurysm using cardiac bypass. JAMA. 1956;162:1158-9.

4. Blanco G, Adam A, Carlo V. A controlled surgical approach to annulo-aortic ectasia. Ann Surg. 1976;183:174-8.
5. Cabrol C, Pavie A, Mesnildrey P, Gandjbakhch I, Laughlin L, Bors V, et al. Long term results with total replacement of the ascending aorta and reimplantation of the coronary arteries. J Thorac Cardiovasc Surg. 1986;91:17-25.

6. Kouchoukos NT, Wareing TH, Murphy SF, Perrillo JB. Sixteen-year experience with aortic root replacement. Results of 172 operations. Ann Surg. 1991;214: 308-18; discussion 318-320.
See Article page 1063.

\section{Commentary: Redo root surgery: Complicated, but feasible}

\author{
T. Brett Reece, MD
}

Aortic root replacement in the setting of previous cardiac surgery can be a formidable undertaking, as described by the authors from Toronto General. At times, identifying the annulus, or even something strong enough to hold annular stitches, can be difficult to recognize. The most intimidating cases can be those that had previous root manipulation, especially given the potential combination of coronary button immobility and tissue friability. Overall, Mazine and colleagues ${ }^{1}$ demonstrate the important considerations required for the optimal care of these difficult patients.

The authors should be praised for demonstrating the risk involved with these procedures. For this cohort, they observed a 30-day mortality of $7.8 \%$. The in-hospital reoperation rate was $14 \%, 2.3 \%$ of which were for bleeding or tamponade. Importantly, the permanent pacemaker rate was $18.8 \%$. Cleary, this rate is above the rate of primary valve or root replacement but speaks to the anatomic difficulties of identifying adequate "annular" tissues to which to sew the conduit. These outcomes are commendable and should be used as an example of what can be achieved with this operation.

The authors eloquently describe important variations required to address redo root anatomy, including both annular reconstruction and alternate coronary implantation techniques. Of note from this study, the authors did not identify extensive

From the Division of Cardiothoracic Surgery, Department of Surgery, University of Colorado School of Medicine, Aurora, Colo.

Disclosures: Author has nothing to disclose with regard to commercial support.

Received for publication Jan 25, 2020; accepted for publication Jan 26, 2020; available ahead of print Feb 7, 2020.

Address for reprints: T. Brett Reece, MD, Department of Surgery, University of Colorado School of Medicine, 12631 E 17th Ave, MS C310, Room 6601, Aurora, CO 80045 (E-mail: Brett.reece@ cuanschutz.edu).

J Thorac Cardiovasc Surg 2021;162:1073-4 0022-5223/\$36.00

Copyright (c) 2020 Published by Elsevier Inc. on behalf of The American Association for Thoracic Surgery

https://doi.org/10.1016/j.jtcvs.2020.01.074

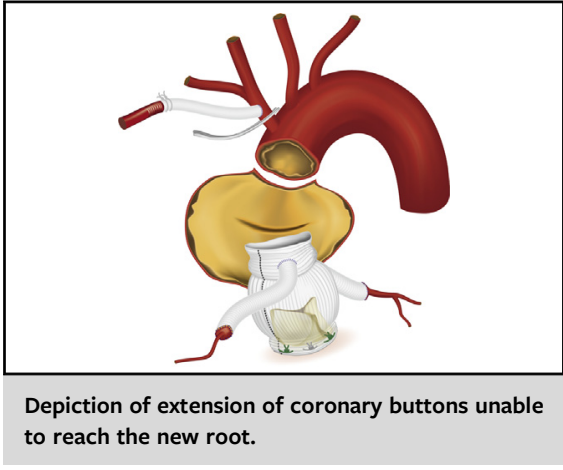

CENTRAL MESSAGE

Aortic root replacement in the setting of previous cardiac procedures requires extreme diligence and a degree of flexibility to deal with common anatomic degeneration to optimize outcomes.

annular reconstruction from endocarditis as a risk of mortality or morbidity. Among other groups, this degree of reconstruction certainly complicates outcomes, but the authors' approach will be a goal for all surgeons embarking on these reconstructions. Although the need for alternative approaches to direct coronary reimplantation arose as a significant risk for significant complications, they were inevitable in $20 \%$ of patients in this series. The approach used was extension rather than a Cabrol-type approach. The authors' bias had been that the Cabrol graft compromises patency; however, optimizing the length of extension and even the conduit used remains evasive for many surgeons. Essentially, the anatomic variations of redo operations can be difficult to deal with, but with experience, the patients can be approached with acceptable but increased risk over primary operations.

Redo root operations require readiness for alternative reimplantation approaches. While these approaches carry more risk, these patients may not be otherwise 